\title{
Zoonotic diseases and human health: The human influenza example
}

\author{
Author: \\ Barry D. Schoub 1 \\ Affiliation: \\ ${ }^{1}$ National Institute for \\ Communicable Diseases, \\ Sandringham, South Africa \\ Correspondence to: \\ Barry Schoub \\ Email: \\ barrys@nicd.ac.za \\ Postal address: \\ Private Bag X4, Sandringham, \\ Johannesburg 2131, \\ South Africa \\ How to cite this proceeding: \\ Schoub, B.D., 2012, 'Zoonotic \\ diseases and human health: \\ The human influenza \\ example', Onderstepoort \\ Journal of Veterinary \\ Research 79(2), Art. \#489, \\ 4 pages. http://dx.doi. \\ org/10.4102/ojvr.v79i2.489

\section{Note:} \\ Proceedings of the \\ Conference of the Southern \\ African Centre for Infectious \\ Disease Surveillance 'One \\ Health' held at the National \\ Institute for Communicable \\ Diseases, Johannesburg, July \\ 2011.
}

C 2012. The Authors. Licensee: AOSIS OpenJournals. This work is licensed under the Creative Commons Attribution License.
Over the past few decades a large number of new and emerging infectious diseases have been recognised in humans, partly because of improved diagnostic technologies and increased awareness and also, partly because of dynamic ecological changes between human hosts and their exposure to animals and the environment (Coker et al. 2011). Some 177 new pathogenic organisms have been recognised to be 'emerging', that is, have newly arisen or been newly introduced into human populations; almost three quarters of these, 130 (73\%), have come from zoonotic origins (Cascio et al. 2011; Cutler, Fooks \& Van Der Poel 2010; Taylor, Latham \& Woolhouse 2001; Woolhouse \& Gowtage-Sequeria 2005). One of the most prevalent and important human infectious disease is influenza, a disease responsible globally for a quarter million deaths annually. In the USA alone the toll from influenza is estimated at 36000 deaths and 226000 hospitalisations, and it ranks as the most important cause of vaccine preventable mortality in that country (CDC 2010). The epidemiological behaviour of human influenza clearly defines it as an emerging infectious disease and the recent understanding of its zoonotic origins has contributed much to the understanding of its behaviour in humans (Fauci 2006).

\section{The classical view of influenza}

Influenza is one of the most enigmatic of human viruses especially when one considers that it was the first human virus to be isolated (Smith, Andrews \& Laidlaw 1933), that the vaccine was one of the first human vaccines to have been developed, in the mid-1940s, and that it is a virus which has been intensively studied since then in animal models, in human volunteers and since the early 1980s at an intense biophysical and biochemical level (Waterfield, Scrace \& Skehel 1981). Yet this virus, despite its public health importance being responsible for causing such a massive burden of illness, is only now in recent times yielding up the secrets of its characteristics and its behaviour in human populations.

The classical view of influenza virus was that of a virus which behaved in one of two ways. Every winter human populations predictably experience seasonal influenza of varying degrees of intensity. Subtle changes in antigenicity as a result of mutational changes in the plastic ribonucleic acid (RNA) genome, termed antigenic drift, ensured that epidemics of influenza in temperate climates would be a feature of every winter. New strains of the virus therefore appeared regularly which would replace existing strains to which the population had built up immunity. On rare occasions, about two or three times per century, a more dramatic change in antigenicity, termed antigenic shift, would result from the introduction of a new gene or genes from an animal reservoir as a result of genetic reassortment of the fragmented genome of the virus. So arose the pandemics of 1918 (the Spanish influenza), 1957 (the Asian influenza) and 1968 (the Hong Kong influenza). With each pandemic a new subtype of influenza A virus would appear to replace its predecessor and it would then become the regular annual seasonal influenza virus. The first upset to this classical concept came with the reappearance of the H1N1 subtype in 1977 after an absence of over 20 years which did not replace the existing H3N2 subtype but circulated together with it and either or both of them would then be responsible for annual seasonal influenza outbreaks (Kilbourne 2006).

A prescient commentary by Scholtissek and Naylor in 1988 drew attention to the risks of future pandemics which could result from developments in aquaculture which promote contacts between humans, ducks and pigs (Scholtissek \& Naylor 1988). In 1997 the first cases of human infections with H5N1 virus were reported from Hong Kong (Claas et al. 1998; Yuen et al. 1998) and subsequently in a number of publications over 50 sporadic and clustered cases of human infections with avian viruses of different subtypes resulting from direct, extended and intimate contact with human poultry were recorded (Alexander 2006; Lee \& Saif 2009; Wong \& Yuen 2006). The fundamental understanding of the ecology of influenza A viruses and the evolution of human viruses was now becoming apparent, namely, that the natural reservoir of influenza virus was avians, especially waterfowl (Subbarao \& Katz 2000). From this reservoir new viruses or new 
genes would periodically cross the species barrier and infect humans either directly or indirectly through an intermediate host such as the pig, or a novel gene or two could be transmitted through reassortment in an intermediate host such as the pig. A second important understanding was the concept that reassortment (the probable mechanism for the 1957 and 1968 pandemics) was not the only mechanism of how new human viruses arose from animal reservoirs but also direct viral transmission from an avian source to humans could play a role in the origin of human pandemics, as was thought to have occurred in the 1918 pandemic (Belshe 2005).

The influenza A (H5N1) outbreak in humans began in Hong Kong in 1997 with 18 cases, six of whom died (Claas et al. 1998; Yuen et al. 1998). The virus then apparently disappeared from human populations for five years reemerging in 2003 in a Hong Kong family who had returned from a trip to mainland China (Peiris et al. 2004). Since then H5N1 disease in humans has spread to 15 countries in Asia, Europe and Africa (WHO 2011). As at 02 August 2011, 563 laboratory-confirmed cases have been reported to $\mathrm{WHO}$, 330 of whom have died - an alarming case fatality of $59 \%$ (WHO 2011). The underlying clinico-pathological reasons for this extraordinarily high case fatality rate, far higher than even the $2.5 \%$ estimated case fatality of the notorious 1918 pandemic (Murray et al. 2006; Taubenberger \& Morens 2006), is still not clear (Abdel-Ghafar et al. 2008; Korteweg \& Gu 2008; Michaelis, Doerr \& Cinatl 2009; Thanh, Van Doorn \& De Jong 2008; Uyeki 2009). Fortunately very few cases of possible human-to-human transmission have been reported (Kandun et al. 2005; Ungchusak et al. 2005). Whether the virus will jump the species barrier and established itself in humans is a public health question of prime concern. A necessary, but not sufficient, first step would need to be a receptor switch from a haemagglutinin with a specificity for the $\alpha$-2,3-galactose saccharide terminal prevalent in the gastrointestinal tract of birds to the $\alpha$-2,6-galactose saccharide terminal prevalent in the upper respiratory tract of mammals including humans (Gabriel, Herwig \& Klenk 2008; Ge \& Wang 2011; Hatta et al. 2007; Uiprasertkul et al. 2005). Given the extremely high case fatality of these sporadic H5N1 cases, a pandemic caused by this virus would indeed be a most formidable prospect. Mortality rates rivaling, or even exceeding, those of the $1918 / 1919$ pandemic are feared - it has been extrapolated from 1918 data that up to 62 million excess deaths could be expected (Murray et al. 2006). Fortunately the receptor switch and sustained crossing of the species barrier has not occurred in the 14 years since the first cases were observed in humans. The one positive outcome of the H5N1 alarm has been the mobilisation of energies to effectively prepare for a future inevitable pandemic (Breiman et al. 2007; Flahault et al. 2006; Uscher-Pines et al. 2006; Webby \& Webster 2003). This pandemic preparedness planning did stand in good stead when the next unexpected pandemic arrived early in 2009.

\section{Swine influenza H1N1}

The swine influenza pandemic of 2009 took all by surprise. Its advent was not in south-east Asia as was usual for pandemics and from where the next pandemic was anticipated, but this time it arose in North America. The first intimation of an impending pandemic was an unusually high rate of hospitalisations of acute respiratory disease in Mexico in late March 2009 and the following month in California. These early observations alerted public health officials to infections with a novel H1N1 influenza A virus of swine origin (Chowell et al. 2011). Within several months the virus had rapidly spread throughout the world and on 11 June 2009 the World Health Organisation (WHO) raised the pandemic alert to level 6 , that is, the formal declaration of a pandemic - the first influenza pandemic since 1968 (WHO 2009). The 2009 pandemic was also a first from a number of other respects (Leung \& Nicoll 2010). Amongst the 'firsts', the 2009 pandemic was the first pandemic where intensive care facilities were available and this provided some intimation as to the severity of this pandemic. The mortality was in fact significantly less than preceding pandemics in most of the world and in many parts even less than the immediately preceding seasonal influenza epidemic. However, what was reported from many countries around the world was an unusually high rate of hospitalisation amongst young patients, many of whom were ostensibly healthy, as well as a heavy load on intensive care facilities (Lipsitch et al. 2009). The relative mildness expressed in terms of mortality rates, led to concerns being expressed, such as by the Council of Europe, as to whether the WHO had not been overhasty in declaring a pandemic (Social Health and Family Affairs Committee of the Parliamentary Assembly of the Council of Europe 2010). This also gave rise to a debate in the literature as to what exactly constitutes a pandemic (Doshi 2011; Morens, Folkers \& Fauci 2009). If the criterion of rapid extra-seasonal spread and heavy involvement of young individuals who often appear to be otherwise healthy, are important elements defining pandemics, then certainly the 2009 pandemic fits into the pandemic definition. Another 'first' was that, for the first time, it was a pandemic not due to the advent of a new subtype of influenza but rather that of an existing seasonal subtype, H1N1, which had become antigenically distant enough from the pre-existing seasonal H1N1 influenza virus so as to behave like a characteristically pandemic virus, especially with respect to the rapidity of its spread worldwide through a largely non-immune population. How the new pandemic virus arose is a story of multiple reassortment events with frequent crossings of the species barrier between humans and animals, especially pigs. The new reassortants went largely undetected and their effects were largely unnoticed because of inadequate surveillance and awareness (Garten et al. 2009; Ilyushina et al. 2010; Trifonov, Khiabanian \& Rabadan 2009). Evidence points to the introduction of influenza A (H1N1) into the pig population at about the same time as the 1918 pandemic in humans and it was then also responsible for widespread disease in pig herds (Zimmer \& Burke 2009). An isolated outbreak of swine influenza A (HswN1) in humans in 1976 amongst military personnel in Fort Dix, New Jersey, resulted in 13 cases of severe respiratory disease and one death, but the infection did not spread further (Gaydos et al. 
2006). A small outbreak of 12 cases of human infection due to a triple reassortant swine influenza virus with genes from swine, avian and human viral sources was detected in the USA between 2005 and 2009 (Dawood et al. 2009). The 2009 pandemic virus now designated as A/California/04/2009 pandemic (H1N1) probably arose from a subsequent reassortment event of this North American reassortant with a Eurasian lineage swine virus (Garten et al. 2009; Ilyushina et al. 2010; Trifonov et al. 2009). Antigenically this new virus had by now achieved a great antigenic distance from the human seasonal influenza A (H1N1) virus circulating at the time resulting in little cross-immunity between them. However the relative sparing of older persons in the 2009 pandemic was largely due to some degree from pre-existing immunity as a result of the structural and antigenic similarity between the haemagglutinin molecule of the pandemic virus and the $\mathrm{H} 1 \mathrm{~N} 1$ viruses which had circulated earlier in the 20th century and to which older persons had been exposed to ( $\mathrm{Xu}$ et al. 2010). Direct transmission from humans to pigs has also been demonstrated (Pereda et al. 2010) and reassortment in pigs, which are susceptible to both human and avian viruses (often referred to as the the 'mixing vessel') pose an ongoing risk to human health. This again emphasises the crucial importance for public health of ongoing robust influenza surveillance of animals such as pigs (Mitka 2010; Vijaykrishna et al. 2010).

\section{Conclusion}

Our understanding of the dynamics of influenza epidemics and pandemics has improved by leaps and bounds since the avian and swine influenza events of the last decade. An essential component of preparedness for future pandemics by public health bodies must now involve a much greater focus on surveillance of animals and birds to avoid being caught out again by surprises such as occurred in 2009 with the swine flu pandemic. The concept of a one health framework to unify the sciences of human, veterinary and ecological health has come none too soon to deal with future emerging infectious diseases in humans (Coker et al. 2011; Kuehn 2010; Mazet et al. 2009). The importance of the one health perspective has been graphically illustrated by one of the most important of the emerging diseases in humans, influenza (Pappaioanou \& Gramer 2010; Powdrill, Nipp \& Rinderknecht 2010).

\section{References}

Abdel-Ghafar, A.N., Chotpitay Asunondh, T., Gao, Z., Hayden, F.G., Nguyen, D.H., De Jong, M.D. et al., 2008, 'Update on avian influenza A (H5N1) virus infection in humans', New England Journal of Medicine 358, 261-273. http://dx.doi. org/10.1056/NEJMra0707279, PMid:18199865

Alexander, D.J., 2006, 'Avian influenza viruses and human health', Developments in Biologicals (Basel) 124, 77-84.

Belshe, R.B., 2005, 'The origins of pandemic influenza-lessons from the 1918 virus', New England Journal of Medicine 353, 2209-2211. http://dx.doi.org/10.1056/ NEJMp058281, PMid:16306515

Breiman, R.F., Nasidi, A., Katz, M.A., Kariuki Njenga, M. \& Vertefeuille, J., 2007 'Preparedness for highly pathogenic avian influenza pandemic in Africa', Emerging Infectious Diseases 13, 1453-1458. http://dx.doi.org/10.3201/eid1310.070400, PMid:18257986

Cascio, A., Bosilkovski, M., Rodriguez-Morales, A.J. \& Pappas, G., 2011, 'The socioecology of zoonotic infections', Clinical Microbiology and Infection 17, 336-342. http://dx.doi.org/10.1111/j.1469-0691.2010.03451.x, PMid:21175957
CDC, 2010, 'Prevention and Control of Influenza with Vaccines', Morbidity and Mortality Weekly Report 59, 1-62. PMid:20075837

Chowell, G., Echevarria-Zuno, S., Viboud, C., Simonsen, L., Tamerius, J., Miller, M.A. et al., 2011, 'Characterizing the epidemiology of the 2009 influenza A/H1N1 pandemic in Mexico', PLoS Medicine 8, e1000436. http://dx.doi.org/10.1371/ pandemic in Mexico', PLOS Medicine 8 ,
journal.pmed.1000436, PMid:21629683

Claas, E.C., Osterhaus, A.D., Van Beek, R., De Jong, J.C., Rimmelzwaan, G.F., Senne, D.A. et al., 1998, 'Human influenza A H5N1 virus related to a highly pathogenic avian influenza virus', Lancet 351, 472-477. http://dx.doi.org/10.1016/S01406736(97)11212-0

Coker, R., Rushton, J., Mounier-Jack, S., Karimuribo, E., Lutumba, P., Kambarage, D. et al., 2011, 'Towards a conceptual framework to support one-health research for policy on emerging zoonoses', Lancet Infectious Diseases 11, 326-331. http:// for policy on emerging zoonoses', Lancet Infecti
dx.doi.org/10.1016/S1473-3099(10)70312-1

Cutler, S.J., Fooks, A.R. \& Van der Poel, W.H., 2010, 'Public health threat of new, reemerging, and neglected zoonoses in the industrialized world', Emerging Infectious Diseases 16, 1-7. http://dx.doi.org/10.3201/eid1601.081467

Dawood, F.S., Jain, S., Finelli, L., Shaw, M.W., Lindstrom, S., Garten, R.J. et al., 2009 'Emergence of a novel swine-origin influenza A (H1N1) virus in humans', New England Journal of Medicine 360, 2605-2615. http://dx.doi.org/10.1056/ NEJMoa0903810, PMid:19423869

Doshi, P., 2011, 'The elusive definition of pandemic influenza', Bulletin of the World Health Organization 89, 532-538. http://dx.doi.org/10.2471/BLT.11.086173, PMid:21734768

Fauci, A.S., 2006, 'Emerging and re-emerging infectious diseases: Influenza as a prototype of the host-pathogen balancing act', Cell 124, 665-670. http://dx.doi. prototype of the host-pathogen balancing act', Cell
org/10.1016/j.cell.2006.02.010, PMid:16497575

Flahault, A., Vergu, E., Coudeville, L. \& Grais, R.F., 2006, 'Strategies for containing a global influenza pandemic', Vaccine 24, 6751-6755. http://dx.doi.org/10.1016/j. global influenza pandemic, Vaccine 24,
vaccine.2006.05.079, PMid:16843574

Gabriel, G., Herwig, A. \& Klenk, H.D., 2008, 'Interaction of polymerase subunit PB2 and NP with importin alpha1 is a determinant of host range of influenza A PB2 and NP with importin alpha1 is a determinant of host range of influenza A
virus', PLoS Pathogens 4, e11. http://dx.doi.org/10.1371/journal.ppat.0040011, virus', PLOS Path:18248089

Garten, R.J., Davis, C.T., Russell, C.A., Shu, B., Lindstrom, S., Balish, A. et al., 2009 'Antigenic and genetic characteristics of swine-origin 2009 A (H1N1) influenza
viruses circulating in humans', Science 325, 197-201. http://dx.doi.org/10.1126/ viruses circulating in humans', Scienc
science.1176225, PMid:19465683

Gaydos, J.C., Top, F.H., Hodder, R.A. \& Russell, P.K., 2006, 'Swine influenza a outbreak, Fort Dix, New Jersey, 1976', Emerging Infectious Diseases 12, 23-28. http://dx.doi. org/10.3201/eid1201.050965, PMid:16494712

Ge, S. \& Wang, Z., 2011, 'An overview of influenza A virus receptors', Critical Reviews in Microbiology 37, 157-165. http://dx.doi.org/10.3109/1040841X.2010.536523, PMid:21438845

Hatta, M., Hatta, Y., Kim, J.H., Watanabe, S., Shinya, K., Nguyen, T. et al., 2007 'Growth of H5N1 influenza A viruses in the upper respiratory tracts of mice', PLoS Pathogens 3, 1374-1379. http://dx.doi.org/10.1371/journal.ppat.0030133, PMid:17922570

Ilyushina, N.A., Kim, J.K., Negovetich, N.J., Choi, Y.K., Lang, V., Bovin, N.V. et al., 2010, 'Extensive mammalian ancestry of pandemic (H1N1) 2009 virus', Emerging Infectious Diseases 16, 314-317. PMid:20113569

Kandun, I.N., Wibisono, H., Sedyaningsih, E.R., Yusharmen Hadisoedarsuno, W., Purba, W., Santoso, H. et al., 2006, 'Three Indonesian clusters of H5N1 virus infection in 2005', New England Journal of Medicine 355, 2186-2194. http:// dx.doi.org/10.1056/NEJMoa060930, PMid:17124016

Kilbourne, E.D., 2006, 'Influenza pandemics of the 20th century', Emerging Infectious Diseases 12, 9-14. http://dx.doi.org/10.3201/eid1201.051254, PMid:16494710

Korteweg, C. \& Gu, J., 2008, 'Pathology, molecular biology, and pathogenesis of avian influenza A (H5N1) infection in humans', American Journal of Pathology 172, 1155-1170. http://dx.doi.org/10.2353/ajpath.2008.070791, PMid:18403604

Kuehn, B.M., 2010, 'Human, animal, ecosystem health all key to curbing emerging infectious diseases', Journal of the American Medical Association 303, 117-118, 124. http://dx.doi.org/10.1001/jama.2009.1896, PMid:20068200

Lee, C.W. \& Saif, Y.M., 2009, 'Avian influenza virus', Comparative Immunoloyg, Microbiology and Disease 32, 301-310.

Leung, G.M. \& Nicoll, A., 2010, 'Reflections on pandemic (H1N1) 2009 and the international response', PLoS Medicine 7.

Lipsitch, M., Riley, S., Cauchemez, S., Ghani, A.C. \& Ferguson, N.M., 2009, 'Managing and reducing uncertainty in an emerging influenza pandemic', New England Journal of Medicine 361, 112-115. http://dx.doi.org/10.1056/NEJMp0904380, PMid:19474417

Mazet, J.A., Clifford, D.L., Coppolillo, P.B., Deolalikar, A.B., Erickson, J.D. \& Kazwala, R.R., 2009, 'A "one health" approach to address emerging zoonoses: The HALI R.R., 2009, A "one health" approach to address emerging zoonoses: The HALI
project in Tanzania', PLOS Medicine 6, e1000190. http://dx.doi.org/10.1371/ project in Tanzania', PLOS Medicine 6,
journal.pmed.1000190, PMid:20016689

Michaelis, M., Doerr, H.W. \& Cinatl, J. (Jnr.), 2009, 'Of chickens and men: Avian influenza in humans', Current Molecular Medicine 9, 131-151. http://dx.doi. org/10.2174/156652409787581565, PMid:19275623

Mitka, M., 2010, 'H1N1 influenza virus reassorting in pigs, poses unknown risk to human health', Journal of the American Medical Association 304, 626-627. http:// dx.doi.org/10.1001/jama.2010.1056, PMid:20699449 
Morens, D.M., Folkers, G.K. \& Fauci, A.S., 2009, 'What is a pandemic?', Journal of Infectious Diseases 200, 1018-1021. http://dx.doi.org/10.1086/644537, PMid:19712039

Murray, C.J., Lopez, A.D., Chin, B., Feehan, D. \& Hill, K.H., 2006, 'Estimation of potential global pandemic influenza mortality on the basis of vital registry data
from the 1918-20 pandemic: A quantitative analysis', Lancet $368,2211-2218$. http://dx.doi.org/10.1016/S0140-6736(06)69895-4

Pappaioanou, M. \& Gramer, M., 2010, 'Lessons from pandemic H1N1 2009 to improve prevention, detection, and response to influenza pandemics from a One Health perspective', ILAR Journal J 51, 268-280.

Peiris, J.S., Yu, W.C., Leung, C.W., Cheung, C.Y., Ng, W.F., Nicholls, J.M. et al., 2004, 'Re-emergence of fatal human influenza A subtype H5N1 disease', Lancet 363, 617-619. http://dx.doi.org/10.1016/S0140-6736(04)15595-5

Pereda, A., Cappuccio, J., Quiroga, M.A., Baumeister, E., Insarralde, L., Ibar, M. et al., 2010, 'Pandemic (H1N1) 2009 outbreak on pig farm, Argentina', Emerging Infectious Diseases 16, 304-307. PMid:20113566

Powdrill, T.F., Nipp, T.L. \& Rinderknecht, J.L., 2010, 'One health approach to influenza: assessment of critical issues and options', Emerging Infectious Diseases 16, e1. http://dx.doi.org/10.3201/eid1608.100673, PMid:20678310

Scholtissek, C. \& Naylor, E., 1988, 'Fish farming and influenza pandemics', Nature 331 215. http://dx.doi.org/10.1038/331215a0, PMid:2827036

Smith, W., Andrewes, C.H. \& Laidlaw, P.P., 1933, 'A virus obtained from influenza patients', Lancet ii, 66-68. http://dx.doi.org/10.1016/S0140-6736(00)78541-2

Social Health and Family Affairs Committee of the Parliamentary Assembly of the Council of Europe, 2010, Hearing on The handling of the H1N1 pandemic: More transparency needed?, viewed 12 August 2011, from http://www.assembly.coe. int/CommitteeDocs/2010/20100126_Statement\%20Wodarg.pdf

Subbarao, K. \& Katz, J., 2000, 'Avian influenza viruses infecting humans', Cellular and Molecular Life Sciences 57, 1770-1784. http://dx.doi.org/10.1007/PL00000657, PMid:11130181

Taubenberger, J.K. \& Morens, D.M., 2006, '1918 Influenza: the mother of all pandemics', Emerging Infectious Diseases 12, 15-22. PMid:16494711

Taylor, L.H., Latham, S.M. \& Woolhouse, M.E., 2001, 'Risk factors for human disease emergence', Philosophical Trnasactions of the Royal Society B: Biological Sciences 356, 983-989. http://dx.doi.org/10.1098/rstb.2001.0888, PMid:11516376

Thanh, T.T., Van Doorn, H.R. \& De Jong, M.D., 2008, 'Human H5N1 influenza: Current insight into pathogenesis', International Journal of Biochemistry and Cell Biology 40, 2671-2674. http://dx.doi.org/10.1016/j.biocel.2008.05.019

Trifonov, V., Khiabanian, H. \& Rabadan, R., 2009, 'Geographic dependence, surveillance, and origins of the 2009 influenza A (H1N1) virus', New England Journal of Medicine 361, 115-119. http://dx.doi.org/10.1056/NEJMp0904572, PMid:19474418
Uiprasertkul, M., Puthavathana, P., Sangsiriwut, K., Pooruk, P., Srisook, K., Peiris, M. et al., 2005, 'Influenza A H5N1 replication sites in humans', Emerging Infectious Diseases 11, 1036-1041. http://dx.doi.org/10.3201/eid1107.041313, Infectious Diseases

Ungchusak, K., Auewarakul, P., Dowell, S.F., Kitphati, R., Auwanit, W., Puthavathana, P. et al., 2005, 'Probable person-to-person transmission of avian influenza A (H5N1)' New England Journal of Medicine 352, 333-340. http://dx.doi.org/10.1056/ NEJMoa044021, PMid:15668219

Uscher-Pines, L., Omer, S.B., Barnett, D.J., Burke, T.A. \& Balicer, R.D., 2006, 'Priority setting for pandemic influenza: an analysis of national preparedness plans, PLoS Medicine 3, e436. http://dx.doi.org/10.1371/journal.pmed.0030436, PMid:17048982

Uyeki, T.M., 2009, 'Human infection with highly pathogenic avian influenza A (H5N1) virus: Review of clinical issues', Clinical Infectious Diseases 49, 279-290. http:// dx.doi.org/10.1086/600035, PMid:19522652

Vijaykrishna, D., Poon, L.L., Zhu, H.C., Ma, S.K., Li, O.T., Cheung, C.L. et al., 2010 'Reassortment of pandemic H1N1/2009 influenza A virus in swine', Science 328 1529. http://dx.doi.org/10.1126/science.1189132, PMid:20558710

Waterfield, M., Scrace, G. \& Skehel, J., 1981, 'Disulphide bonds of haemagglutinin of Asian influenza virus', Nature 289, 422-424. http://dx.doi.org/10.1038/289422a0, PMid:7464912

Webby, R.J. \& Webster, R.G., 2003, 'Are we ready for pandemic influenza?', Science 302, 1519-1522. http://dx.doi.org/10.1126/science.1090350, PMid:14645836

WHO, 2009, World now at the start of 2009 influenza pandemic, viewed 12 August 2011, from http://who.int/mediacentre/=news/statements/2009/h1n1 pandemic_phase6_20090611/en/index.htm1\#

WHO, 2011, Cumulative number of confirmed human cases of avian influenza A (H5N1) reported to $W H O$, viewed 12 August 2011, from http://www.who.int/csr/ disease/avian_influenza/country/cases_table_2011_08_02/en/index.html\#

Wong, S.S. \& Yuen, K.Y., 2006, 'Avian influenza virus infections in humans', Ches 129 156-168. http://dx.doi.org/10.1378/chest.129.1.156, PMid:16424427

Woolhouse, M.E. \& Gowtage-Sequeria, S., 2005, 'Host range and emerging and reemerging pathogens', Emerging Infectious Diseases 11, 1842-1847. http:// dx.doi.org/10.3201/eid1112.050997, PMid:16485468

Xu, R., Ekiert, D.C., Krause, J.C., Hai, R., Crowe, J.E. (Jnr) \& Wilson, I.A., 2010, 'Structural basis of preexisting immunity to the 2009 H1N1 pandemic influenza virus', Science 328, 357-360. http://dx.doi.org/10.1126/science.1186430, PMid:20339031

Yuen, K.Y., Chan, P.K., Peiris, M., Tsang, D.N., Que, T.L., Shortridge, K.F. et al., 1998 'Clinical features and rapid viral diagnosis of human disease associated with avian influenza A H5N1 virus', Lancet 351, 467-471. http://dx.doi.org/10.1016/S0140influenza A H5N1

Zimmer, S.M. \& Burke, D.S., 2009, 'Historical perspective - Emergence of influenza A (H1N1) viruses', New England Journal of Medicine 361, 279-285. http://dx.doi. org/10.1056/NEJMra0904322, PMid:19564632 